\title{
MORPHOLOGICAL CHARACTERIZATION AND REPRODUCTIVE ASPECTS IN GENETIC VARIABILITY STUDIES OF FORAGE PEANUT
}

\author{
Marilda Augusta Peres Oliveira ${ }^{1,3}$; José Francisco Montenegro Valls, 2,4 \\ ${ }^{1}$ UNESP/IB - Depto. de Genética, Rubião Júnior, s/n - 18680-000 - Botucatu, SP - Brasil. \\ ${ }^{2}$ Embrapa Recursos Genéticos e Biotecnologia. SAIN Pq. Estação Biológica, C.P. 02372 - 70770-900 - Brasília, \\ DF - Brasil. \\ ${ }^{3}$ CAPES scholarship. \\ ${ }^{4} \mathrm{CNPq}$ scholarship. \\ *Corresponding author<valls@cenargen.embrapa.br>
}

\begin{abstract}
Morphological characterization and the study of reproductive behavior are important procedures to identify desirable traits of progenitors to be included in breeding programs. Morphological descriptors and the reproductive behavior of parental accessions of the legumes Arachis pintoi Krapov \& W.C.Gregory and $A$. repens Handro were analyzed looking for the probable causes of seed production variability. Morphological and reproductive characterization were used for the estimation of the genetic variability of five $A$. pinto $i$ and two $A$. repens accessions, with crosses being conducted in a greenhouse. Parents and hybrids have shown high pollen stainability, regular meiosis $(2 \mathrm{n}=20)$, and presented distinctive reproductive behaviors: $A$. pintoi accessions GK 12787, V 13468 and V 6791-wf are prolific seed producers, while $A$. pintoi V 13167, V 13338 and $A$. repens Nc 1579 and $\mathrm{Nc}$ 1578, rarely produce seeds. Intraspecific crosses generated fertile $\mathrm{F}_{1}$ and $\mathrm{F}_{2}$ hybrids from five combinations. Interspecific crosses produced sterile $\mathrm{F}_{1}$ hybrids. Stigma morphology and distinct mode of reproduction present among accessions suggest possible barriers for seed production in some cross-combinations. Euclidian distance range between parents was 0.20 to 5.52. Accessions GK 12787 and Nc 1579 presented the maximum distance: 5.52, and V 13468 and Nc 1579 the minimum distance: 0.20. The Euclidian distance was considered an adequate methodology to study genetic diversity of parental accessions.
\end{abstract}

Key words: crossability, germplasm, legumes, wild peanut

\section{CARACTERIZAÇÃO MORFOLÓGICA E ASPECTOS REPRODUTIVOS NO ESTUDO DA VARIABILIDADE GENÉTICA EM AMENDOIM FORRAGEIRO}

\begin{abstract}
RESUMO: A caracterização morfológica e o estudo do comportamento reprodutivo são procedimentos importantes para definir caracteres desejáveis nos progenitores a serem incluídos em programas de melhoramento. Descritores morfológicos foram aplicados e foi avaliado o comportamento reprodutivo na busca das prováveis causas da produção variável de sementes entre acessos parentais das leguminosas Arachis pintoi Krapov \& W.C.Gregory e $A$. repens Handro. A caracterização morfológica e reprodutiva foi utilizada para avaliação da variabilidade genética em cinco acessos de $A$. pintoi e dois acessos de $A$. repens e os cruzamentos foram realizados em casa de vegetação. Os parentais apresentaram alta corabilidade do pólen, meiose regular (2n=20), e variação no comportamento reprodutivo: $A$. pintoi GK 12787, V 13468 e V 6791wf são prolíficos, enquanto $A$. pintoi $\mathrm{V} 13167, \mathrm{~V} 13338$ e $A$. repens $\mathrm{Nc} 1579$ e Nc 1578 raramente produzem sementes. Os cruzamentos intra-específicos geraram híbridos $\mathrm{F}_{1}$ e $\mathrm{F}_{2}$ férteis em cinco combinações. Os cruzamentos interespecíficos produziram híbridos $\mathrm{F}_{1}$ estéreis. A morfologia do estigma e o modo de reprodução presente nos acessos sugerem possíveis barreiras para a produção de sementes em alguns cruzamentos. A Distância Euclidiana entre os parentais variou de 0,20 a 5,52. Os acessos GK 12787 e Nc 1579 apresentaram a maior distância $(5,52)$ e V 13468 e Nc 1579 apresentaram a menor distância $(0,20)$. A Distância Euclidiana foi considerada uma metodologia adequada para estudos de diversidade genética em acessos parentais.

Palavras-chave: cruzabilidade, germoplasma, leguminosas, amendoim silvestre
\end{abstract}

\section{INTRODUCTION}

Exploitation of legume species as prospective new cultivars for pasture establishment has intensified the agronomic evaluation of Arachis pintoi Krapov. \& W.C.Gregory, a promising Brazilian legume, which has shown great tolerance to stress and grazing, having a good persistence. Attributes for additional uses, such as cover- 
crops for erosion control and reduction of weed invasion and gardening were also identified in its accessions (Argel \& Pizarro, 1992; Argel \& Villarreal, 1998; Cook \& Crosthwaite, 1994). An effort towards germplasm enrichment, conducted at "Embrapa Recursos Genéticos e Biotecnologia", Brazil, has increased the number of available accessions of $A$. pintoi and the related $A$. repens Handro, the other species of the taxonomic section Caulorrhizae, to 150 . Hybrid combinations of A. pintoi and $A$. repens are also considered desirable. Ideally, a perennial, persistent legume could be produced combining in a single genotype the best traits of these species (Firth \& Wilson, 1995).

Wild species of Arachis are generally accepted as autogamous, by analogy to the cultivated peanut, $A$. hypogaea L., but differences in stigma morphology and pollination behavior have been noted for both annual and perennial species (Lu et al., 1990). Arachis hypogaea is regarded as a self-pollinated, allotetraploid crop, $(2 \mathrm{n}=40)$, contrary to most wild Arachis species, which are diploid $(2 n=20)$. Variability in reproductive characteristics is recognized in this genus. Sexual reproduction of seed-producing species is the usual process, although apomixis is also indicated as possible for some species of Arachis, under certain conditions, and the vegetative propagation has also been reported (Simpson et al., 1994). A better understanding of the genetic variation, encompassed by each germplasm accession of Arachis species and by the collection as a whole, can only be attained by adequate characterization (Valls et al., 1995). The morphological and molecular variation observed in section Caulorrhizae (Bertozo \& Valls, 2001; Gimenes et al., 2000; Monçato, 1995; Valente et al., 2001) supports the investigation of the level of genetic variability available in this section.

Genetic variability in a population is a parameter that can be easily measured through the genetic distance between parents (Cowen \& Frey, 1987). Intraspecific and interspecific crosses have been used in the characterization of new genetic materials of cultivated species, well known for their phenology and reproduction. Artificial crosses yield valuable information on reproductive behavior, genetic barriers and, in the case of perennial Arachis species, potential for inclusion in forage breeding programs. For a better understanding of the phylogenetic relationship within the genus Arachis, Gregory \& Gregory (1979) conducted many crosses using accessions between and within taxonomic sections, and obtained only one interspecific hybrid between $A$. pintoi and $A$. repens. Other crosses, between members of section Caulorrhizae and accessions of different sections were successfully obtained, but the progeny was sterile (Krapovickas \& Gregory, 1994).

This work aims to evaluate morphological and reproductive aspects, including seed production and crosses, in accessions of $A$. pinto $i$ and $A$. repens, for the estimation of genetic variability and to indicate the best cross-combinations from divergent progenitors.

\section{MATERIAL AND METHODS}

Plant materials - Five accessions of $A$. pinto $i$ and two of $A$. repens originally collected in the nature in the Brazilian States of Bahia, Minas Gerais and Goiás, were maintained in a greenhouse at Embrapa Recursos Genéticos e Biotecnologia (Embrapa/Cenargen), BrasiliaDF, Brazil. The same parental accessions were grown in pots outside the greenhouse to permit normal self-pollination, and during the same period crosses were made (Oliveira, 1997). Parental accessions presented distinct morphological characteristics, such as the presence or absence of bristles in petioles and leaflets, and distinct colors of the flower standard (Table 1).

Pollen viability and stigma morphology - Attributes such as pollen stainability, stigma morphology and variation in fruit production of the parental accessions were previously evaluated under cultivation (Oliveira \& Valls, 2002) (Table 2). The acetocarmine and glycerin $(1: 1)$ staining method (Resslar \& Gregory, 1979) was used to estimate pollen stainability for both parents and hybrids.

Table 1 - Parental accessions of Arachis pintoi and A. repens and descriptors applied for their morphological characterization.

\begin{tabular}{lccccccc}
\hline \multicolumn{7}{c}{ Parental Accessions $^{1}$} \\
\hline Characters & GK 12787 & V 13167 & V 13338 & V 13468 & V 6791-wf & Nc 1579 & Nc 1578 \\
\hline Bristles on internode & present & present & present & absent & present & absent & Present \\
Bristles on leaflets & present & absent & absent & present & absent & absent & Absent \\
Shape of leaflets & round & elliptic & elliptic & elliptic & elliptic & lancet & Lancet \\
${ }^{2}$ Length/ width distal & 1.6 & 1.5 & 1.7 & 1.7 & 1.5 & 2.12 & 2.6 \\
${ }^{2}$ Length/ width basal & 1.7 & 1.7 & 2.0 & 1.8 & 1.8 & 2.3 & 2.8 \\
\multirow{2}{*}{ Flower color } & yellow & orange & cream & light-cream & white & yellow & orange \\
& (3-7A) & $(4-8 \mathrm{~A})$ & $(2-6 \mathrm{~A})$ & $(2-5 \mathrm{~A})$ & $(2-3 \mathrm{~A})$ & $(4-7 \mathrm{~A})$ & $(5-8 \mathrm{~A})$ \\
\hline
\end{tabular}

${ }^{1}$ Collectors: $\mathrm{GK}=$ W.C.Gregory \& A.Krapovickas, $\mathrm{Nc}=$ N.M.S.Costa, V=J.F.M.Valls.

${ }^{2}$ Relation of length to width of distal and basal leaflets

${ }^{3}$ Using scale of KORNEUP, A.; WASNSCHER, J.H. Methuen Handbook of Colour. (3ed.) London: Methuen, 1978 (Reprinted 1989). 
The stigma morphology was classified based on the amount and length of hairs surrounding the tip of the stigma.

\section{Morphological characterization and hybridization -} Fourteen morphological characteristics of the parental accessions and hybrids were evaluated. Measurements were taken on lateral braches in triplicate, as follows: (1) number of bristles on the rachis-BR; (2) number of bristles on the internode-BI; (3) number of bristles on leaflets-BL; (4) rachis length-LR; (5) petiole length-LP; (6) rachis thickness-TR; (7) petiole thickness-TP; (8) internode thicknessTINO; (9) length of distal leaflets-LDL; (10) width of distal leaflets-WDL; (11) length of basal leaflets-LBL (12) width of basal leaflets-WBL; (13) total length of stipule-LST; and (14) length of adnate part only-LSAP. Artificial hybridization was based on the technique adopted by Nigam et al. (1990). Distinct cross-combinations for $A$. pintoi accessions were based on the distinct colors of flower standard (Table 1). Four months after the onset of each crossing period, cross-pollinated seeds were recovered. On the basis of morphological traits, seedlings were easily classified either as hybrids or maternal.

Genetic distance- Genetic divergence among the genotypes was measured by the Euclidian distance method (Cruz \& Regazzi, 1994) and fourteen morphological descriptors were used to estimate the genetic distance. The Euclidian distance between two progenitors i and i' was calculated as follows:

dii' $^{\prime}=\sqrt{1 / \mathrm{n} \Sigma \mathrm{j}\left(\mathrm{xij}-\mathrm{xi}^{\prime} \mathrm{j}\right)^{2}}$

\section{RESULTS AND DISCUSSION}

Seed production by parents and hybrids - Accessions V 6791-wf, GK 12787 and V 13468 are prolific seed producers, whereas accessions V 13167, V 13338, Nc 1578 and Nc 1579 are poor seed producers when in isolation, under greenhouse conditions (Oliveira \& Valls, 2002). Seed production of the parental accessions outside the greenhouse was similar to that obtained in isolation, except for accession V 13338, that was more prolific in open conditions (Table 2). $F_{1}$ hybrids also produced variable amounts of seeds in isolation, but no direct relation was observed between parental accessions and intraspecific $F_{1}$ hybrids prolificity (Table 3 ). Poor seed producing parent generated $\mathrm{F}_{1}$ hybrids in the intraspecific crosses, which produced a large number of $\mathrm{F}_{2}$ seeds. This high seed yield may be associated to good cross-combination among accessions, since these accessions were quite distant with respect to the mode of reproduction and seed production (Table 2). No $F_{2}$ seeds were developed from interspecific crosses, although pollen viability was high in the parents (Table 2) and $F_{1}$ hybrids (Table 3 ). The completely sterile $F_{1}$ hybrids of interspecific crosses support the taxonomic classification of $A$. repens and $A$. pintoi like two distinct species as proposed by Krapovickas \& Gregory (1994), on the basis of morphological characters only.

Identification of hybrids was achieved by using the flower standard color, an easily observable morphological character. Hybrids between accessions of $A$. pintoi exhibited a standard yellow flower, even when the female progenitor had other colors. When parents shared the same flower color, hybrids between $A$. pintoi and $A$. repens were detected by the very distinct leaf and internode morphology.

Reproductive aspects - Pollen stainability varied in parents (79.5-100\%) and both intraspecific (71.2-97.8\%) and interspecific (55.4-99.0\%) hybrids. The lowest count of $55.4 \%$ was shown in an $\mathrm{F}_{1}$ A. pintoi x A. repens. However, other $\mathrm{F}_{1}$ hybrids of the same parent combination presented high pollen counts, reaching 96.6\% (Table 3). Morphology of the stigmatic tip varied among parental accessions, from a tip of stigma surrounded by many long hairs in Nc 1579, to an almost glabrous tip in GK 12787

Table 2 - Preliminary data on the reproductive biology of parental accessions of Arachis pintoi and A. repens used in the crossing program.

\begin{tabular}{|c|c|c|c|c|c|}
\hline \multirow{2}{*}{ Accession } & \multirow{2}{*}{$\begin{array}{l}\% \text { Pollen } \\
\text { stainability }\end{array}$} & \multirow{2}{*}{$\begin{array}{l}\text { Hairs on tip of } \\
\text { stigma }^{1}\end{array}$} & \multicolumn{2}{|c|}{ Seed production } & \multirow{2}{*}{$\begin{array}{c}\text { Inferred reproductive } \\
\text { behavior }\end{array}$} \\
\hline & & & open $^{2}$ & greenhouse & \\
\hline \multicolumn{6}{|l|}{ A. pintoi } \\
\hline GK 12787 & 79.5 & $\mathrm{~S} / \mathrm{F}$ & High & High & Autogamy \\
\hline V 13167 & 99.8 & $\mathrm{I} / \mathrm{M}$ & Low & Rare & Self-incompatibility \\
\hline V 13338 & 94.8 & $\mathrm{~S} / \mathrm{F}$ & High & Rare & Self-incompatibility \\
\hline V 13468 & 97.6 & $\mathrm{I} / \mathrm{F}$ & High & High & Autogamy \\
\hline V 6791-wf & 97.6 & $\mathrm{~S} / \mathrm{F}$ & High & High & Autogamy \\
\hline \multicolumn{6}{|l|}{ A. repens } \\
\hline Nc 1578 & 98.2 & $\mathrm{~L} / \mathrm{M}$ & None & None & Allogamy \\
\hline Nc 1579 & 100 & $\mathrm{~L} / \mathrm{M}$ & None & None & Allogamy \\
\hline
\end{tabular}

${ }^{1} \mathrm{~S}=$ short, I-intermediate, L-long $/ \mathrm{F}=$ few, $\mathrm{I}=$ intermediate, $\mathrm{M}=$ many.

${ }^{2}$ High open pollinated seeds $=250-50 /$ pot, low $<50 /$ pot, none $=0$. 
Table 3 - Data from intraspecific and interspecific crosses of Arachis species from section Caulorrhizae showing correspondence of pollen stainability and hairs on stigma in $\mathrm{F}_{1}$ hybrids, and seeds produced in the $\mathrm{F}_{2}$ progenies.

\begin{tabular}{lccccc}
\hline A. pintoi x A. pintoi & Artificia crosses & $\mathrm{F}_{1}$ seeds & Pollen stainability & Hairs on stigmas $_{1}$ & $\mathrm{~F}_{2}$ seeds \\
\hline V 13167 x V 6791-wf & 109 & 7 & 97.8 & S/M & 37 \\
V 13167 x GK 12787 & 107 & 5 & $72.6-97.4$ & S/I; S/F & 170 \\
V 13338 x GK 12787 & 79 & 3 & $67.8-79.6$ & S/F; L/I2 & 106 \\
V 13468 x GK 12787 & 82 & 7 & $71.2-82.7$ & S/M; S/F & 31 \\
V 13468 x V 13167 & 81 & 3 & $77.2-79.4$ & L/I; I/I & 8 \\
\hline A.pintoi x A.repens & & & & & \\
GK 12787 x Nc 1579 & 54 & 7 & $55.4-96.6$ & L/M; I/I & 0 \\
V 13167 x Nc 1578 & 188 & 7 & $98.0-99.0$ & S/I & 0 \\
\hline
\end{tabular}

${ }^{1} \mathrm{~S}=$ short, I-intermediate, L-long / $\mathrm{F}=$ few, I=intermediate, $\mathrm{M}=$ many.

${ }^{2}$ Distinct from other stigmas from hybrids of the same cross-combination.

(Table 2). Hybrids also presented variation in stigmatic morphology (Table 3). F hybrids A. pintoi x A. pintoi presented seed production in plants with short stigma hairs, but none in plants with long hairs. The impact of the morphology of the tip of the stigma in the open and self-pollination conditions was not evaluated. It was observed, however, that low seed production and the presence of dense and long hairs surrounding the stigma are associated traits. Differences in this direction where shown by distinct $F_{1}$ hybrids deriving from the V 13338 x GK 12787 combination. The variation in the stigma morphology was associated to seed prolificity ( $\mathrm{Lu}$ et al., 1990). The authors reported that annual species have short stigmatic hairs, while perennials have longer stigmatic hairs, corresponding to a lower seed production.

However, section Caulorrhizae poses a very distinct situation, where all accessions are perennial and variation is found regarding seed prolificity and stigmatic morphology. Pollen stainability rates of the intraspecific and interspecific $\mathrm{F}_{1}$ hybrids were above $70 \%$ (exception for one hybrid with $55.4 \%$ ) and meiotic behavior was normal (data not shown). These plants should not have problems regarding fertilization and viable seed production, a common trait in other Arachis species (Niles \& Quesenberry, 1992). Nevertheless, the presence of long hairs at the tip of the stigma may establish a barrier for pollination. The persistence, for many years, of the perennial hybrids obtained in the present study, as well as of their parents and progenies, provides a favorable basis for further investigation on the variability of this character, already observed in the $\mathrm{F}_{1}$ progeny.

Application of descriptors and genetic distance - Previous morphological studies characterized GK 12787, V 13338, V 13167 and Nc 1579 accessions (Monçato, 1995) and, through the application of descriptors to V 13468 , V 6791-wf and Nc 1578, the study was completed (Table 2). The fourteen descriptors applied to parental individuals and $\mathrm{F}_{1}$ hybrids confirm the large morphological variability in section Caulorrhizae. The relation of length to width of leaflets was previously used for distinction of species within the section. In the present work, the descriptors were effective and they were sufficiently discriminative to separate species and accessions (Table 1). According to previous characterization, A. repens (GKP 10578 ) presents leaflets 2.5 times longer than wide, while A. pintoi leaflets (GK 12787) present a relation near 2.0 (Krapovickas \& Gregory, 1994). This descriptor confirmed the proportion of length by width, throughout the $A$. pintoi and A. repens accessions. Parents presented variation in BR (0-3 grade), BI (0-3 grade), BL (0-2.6 grade), LR (4.5-8.8 mm), LP (13.2-41.8 mm), TR (0.8$1.5 \mathrm{~mm})$, TP (0.9-1.8 mm), TINO (1.9-3.5 mm), LDL (19.5-38.0 mm), WDL (9.2-23.3 mm), LBL (18.0-33.7 $\mathrm{mm})$, WBL $(8.2-19.3 \mathrm{~mm})$, LST $(10.5-20.5 \mathrm{~mm})$ and LSAP (4.3- $8.7 \mathrm{~mm}$ ). Morphological characters that exhibited more variation in the twenty hybrids, as compared to parents, were: LR (5.0-10.2 mm), LP (10.2-36.5 mm), TR (1.0-1.7 mm), TP (1.0- $1.7 \mathrm{~mm})$, TINO (2.2-4.4 mm), LDL (25.7-39.9 mm), WDL (13.0-27.4 mm), LBL (21.7$34.2 \mathrm{~mm})$, WBL $(13.2-23.9 \mathrm{~mm})$, LST $(13.8-26.3 \mathrm{~mm})$ and LSAP (6.7-14.1 mm) (Table 4).

Regarding other morphological characteristics analyzed in parental accessions, the Euclidian distance (Ali et al., 1995) between parents ranged from 5.52 to 0.20 (Table 5). The lowest genetic distance $(0.20)$ was found between Nc 1579 and V 13468, a morphologically intermediate accession of $A$. pintoi, exhibiting leaflet size like typical $A$. pinto $i$, but leaflet shape like $A$. repens. Under field conditions, V 13468 could easily be confused with $A$. repens $\mathrm{Nc} 1579$. The maximum distance (5.52) was verified between the most morphologically divergent progenitors, A. pintoi GK 12787 and A. repens Nc 1579. The second highest Euclidian distance (4.27) was found between V 13468 and GK 12787. These two accessions presented the lowest and highest genetic distances, respectively, in relation to $A$. repens $\mathrm{Nc} 1579$ (Table 5). The maximum distance of 5.52 verified in the parental accessions originated the most vigorous hybrid in field experiments (Oliveira, 1997). The two accessions GK 12787 
Table 4 - Morphological descriptors applied in triplicate to the parental accessions and $\mathrm{F}_{1}$ hybrids of Arachis species, section Caulorrhizae.

BR- bristles on rachis; BI- bristles on internodes; BL- bristles on leaflets; LR- length of rachis; LP- length of petioles; TR- thickness of rachis; TP- thickness of petioles; TINO- thickness of internode; LDL- length of distal leaflets; WDL- width of distal leaflets; LBL- length of basal leaflets; WBL- width of basal leaflets; LST- total length of stipule; LSAP-length of adnate part of stipule.

*Morphological descriptors were not applied to hybrids from every cross-combination.

(grown from seeds of the type-collection of $A$. pintoi) and Nc 1579 (a morphologically typical accession of $A$. repens) seem to represent extreme morphological types on a continuum, with most of the accessions having intermediate states or a reticular association of characters (Valls \& Simpson, 1994).

Genetic distance can be an adequate parameter for choosing parental combinations in a crossing program (Cowen \& Frey, 1987) involving forage peanut accessions. Information obtained through the investigation of reproductive behavior, stigma morphology and other morphological features provided some insights about the possible causes for the variable amount of seeds produced in distinct cross-combinations.
The crosses exposed the genetic variability available in forages species of section Caulorrhizae and have indicated the possibility of new genotype development encouraging further exploitation of their desirable characteristics for direct use in cultivated pastures and genetic breeding programs.

\section{ACKNOWLEDGEMENTS}

This work was supported by Coordenadoria de Aperfeiçoamento de Pessoal de Ensino Superior (CAPES), Conselho Nacional de Desenvolvimento Científico e Tecnológico (CNPq) and Embrapa Recursos Genéticos e Biotecnologia, Brasília, DF, Brazil. 
Table 5 - Genetic distances between seven Arachis pintoi and A. repens parents calculated on the basis of 14 morphological traits.

\begin{tabular}{|c|c|c|c|c|c|c|}
\hline & $\begin{array}{c}\text { A. repens } \mathrm{Nc} \\
1579\end{array}$ & $\begin{array}{c}\text { A. pintoi } \mathrm{V} \\
13338\end{array}$ & $\begin{array}{c}\text { A. pintoi } \\
\text { V 6791-wf }\end{array}$ & $\begin{array}{l}\text { A. pintoi } \\
\text { V } 13468\end{array}$ & $\begin{array}{l}\text { A. pintoi } \\
\text { V } 13167\end{array}$ & $\begin{array}{c}\text { A. repens } \mathrm{Nc} \\
1578\end{array}$ \\
\hline $\begin{array}{l}\text { A. pintoi } \\
\text { GK } 12787\end{array}$ & 5.52 & 2.36 & 1.63 & 4.27 & 1.53 & 2.02 \\
\hline $\begin{array}{l}\text { A. repens } \\
\text { Nc } 1579\end{array}$ & & 1.61 & 2.76 & 0.20 & 1.86 & 1.45 \\
\hline $\begin{array}{l}\text { A. pintoi } \\
\text { V } 13338\end{array}$ & & & 1.24 & 1.32 & 0.82 & 0.48 \\
\hline $\begin{array}{l}\text { A. pintoi } \\
\text { V 6791-wf }\end{array}$ & & & & 2.10 & 0.59 & 0.91 \\
\hline $\begin{array}{l}\text { A. pintoi } \\
\text { V } 13468\end{array}$ & & & & & 1.89 & 1.74 \\
\hline $\begin{array}{l}\text { A. pintoi } \\
\text { V } 13167\end{array}$ & & & & & & 0.31 \\
\hline
\end{tabular}

\section{REFERENCES}

ALI, M.; COPELAND, L.O.; ELIAS, S.G.; KELLY, J.D. Relationship between genetic distance and heterosis for yield and morphological traits in winter canola (Brassica napus L.). Theoretical Applied Genetics, v.91, p.118-121, 1995.

ARGEL, P.J.; PIZARRO, E.A. Germplasm case study: Arachis pintoi. In: CIAT. Pastures for the tropical lowlands: CIAT contribution. Cali: CIAT, 1992. p.57-73.

ARGEL, P.J.; VILLARREAL, M. Nuevo maní forrajero perenne (Arachis pintoi Krapovickas \& Gregory). Cultivar Porvenir (CIAT 18744): Leguminosa herbácea para alimentación animal, el mejoramiento y conservación del suelo y el embellecimento del paisaje. San José: Ministerio de Agricultura y Ganadería de Costa Rica (MAG), 1998. 32p. (Boletín Técnico.)

BERTOZO, M.R.; VALLS, J.F.M. Seed storage protein electrophoresis in Arachis pintoi and A. repens (Leguminosae) for evaluating genetic diversity. Genetic Resources and Crop Evolution, v.48, p.121-130, 2001.

COWEN, N.M.; FREY, K.F. Relationship between three measures of genetic distance and breeding behavior in oats (Avena sativa L.). Genome, v.29, p.97-106, 1987.

COOK, B.G.; CROSTHWAITE, I.C. Utilization of Arachis species as forage. In: SMARTT, J. (Ed.) The groundnut crop. London: Chapman \& Hall, 1994. p.624-657.

CRUZ, C.D.; REGAZZI, A.J. Modelos biométricos aplicados ao melhoramento genético. Viçosa: UFV, Imprensa Universitária,1994. 390p.

FIRTH, D.J.; WILSON, G.P.M. Preliminary evaluation of species for use as permanent ground cover in orchards on the north coast of New South Wales. Tropical Grassland, v.29, p.18-27, 1995.

GIMENES, M.A.; LOPES, C.R.; GALGARO, M.L.; VALLS, J.F.M.; KOCHERT, G. Genetic variation and phylogenetic relationships based on RAPD analysis in section Caulorrhizae, genus Arachis (Leguminosae). Euphytica, v.116, p.187-195, 2000.

GREGORY, M.P.; GREGORY, W.C. Exotic germplasm of Arachis L. interspecific hybrids. Journal of Heredity, v.70, p.185-193, 1979.
KRAPOVICKAS, A.; GREGORY, W.C. Taxonomía del género Arachis. (Leguminosae). Bonplandia, v.8, p.1-186, 1994.

LU, J.; MAYER, A.; PICKERSGILL, B. Stigma morphology and pollination in Arachis L . (Leguminosae). Annals of Botany, v.66, p.73-82, 1990.

MONÇATO, L. Caracterização morfológica de germoplasma de espécies de Arachis secção Caulorrhizae pela análise multivariada. Botucatu: UNESP, 1995. 122p. (Dissertação - Mestrado)

NILES, W.L.; QUESENBERRY, K.H. Pollen germination of Rhizoma peanut cv. Florigraze. Peanut Science, v.19, p.105-107, 1992.

NIGAM, S.N.; RAO, M.J.V.; GIBBONS, R.W. Artificial hybridization in groundnut. Hyderabad: ICRISAT, 1990. 27p. (Information Bulletin, 29).

OLIVEIRA, M.A.P. Avaliação da distância genética entre espécies de Arachis da secção Caulorrhizae pela hibridação intraespecífica e interespecífica. Botucatu: UNESP, 1997. 99p. (Tese - Doutorado)

OLIVEIRA, M.A.P.; VALLS, J.F.M. Produção de híbridos de amendoim forrageiro por meio de hibridação artificial. Pesquisa Agropecuária Brasileira, v.37, p.885-888, 2002.

RESSLAR, P.M.; GREGORY, W.C. A cytological study of three diploid species of genus Arachis L. Heredity, v.70, p.13-16, 1979.

SIMPSON, C.E.; VALLS, J.F.M.; MILES, J.W. Reproductive biology and potential for genetic recombination in Arachis. In: KERRIDGE, P.C.; HARDY, B. (Ed.) Biology and agronomy of forage Arachis. Cali: CIAT, 1994. 209p. (CIAT. Publication, 204).

VALENTE, S.E.; COELHO, P.J.A.; GIMENES, M.A.; VALLS, J.F.M.; LOPES, C.R. Analysis of isoenzimatic variation in accessions of Arachis pintoi derived from its original germplasm collection. Pasturas Tropicales, v.23, p. 9-13, 2001.

VALLS, J.F.M.; SIMPSON, C.E. Taxonomy, natural distribution, and attributes of Arachis. In: KERRIDGE, P.C.; HARDY, B. (Ed.) Biology and agronomy of forage Arachis. Cali: CIAT, 1994. 209p. (CIAT. Publication, 204)

VALLS, J.F.M.; SIMPSON, C. E.; RAO, V.R. Collecting wild species of Arachis. In: GUARINO, L.; RAO, V.R.; REID, R. (Ed.) Collecting plant genetic diversity. Technical guidelines. Wallingford: CAB International, 1995. p.677-684.

Received January 04, 2002 